\title{
Western Song Singing Model to Improve Junior High School Students' Singing Ability in Indonesia
}

\author{
Wadiyo $^{\bowtie}$, Udi Utomo, Slamet Haryono \\ Department of Drama, Dance, and Music, Faculty of Languages and Arts, \\ Universitas Negeri Semarang, Indonesia
}

Received: March 15, 2019. Revised: May 2, 2019. Accepted: June 22, 2019

\begin{abstract}
Singing activities are general activities that seem very easy. It could be said that anyone can sing. However, to be able to sing well and correctly seems to need to be learned. For Junior High Schools in Indonesia, singing activities are included in the teaching material of cultural arts sub music material. This study aims to "analyze how singing activities are taught in classes on learning Art and sub music material". The approach of this research is interdisciplinary which involves music disciplines and music learning. The research method applied is interpretive qualitative. The research location is Semarang, by involving Semarang Junior High School Students and Teachers as the subject of research. Data collection techniques used in this research is observation, interviews, and documentation studies. The data validity technique is using data source triangulation. Data analysis techniques used in this research are interactive flow. The results showed that teachers taught singing, both in classes Vll, Vlll, and Vlll. Singing activity for class Vll focused on basic singing techniques. The eighth grade is focused on singing, whose vocals or singing techniques are more applied to singing local songs and Nusantara songs. Meanwhile, singing activity in class VIII is more focused on improvising any song. This study concludes that teachers always emphasize the use of western song singing models as a basic technique, regardless of the type of song used in the learning process.
\end{abstract}

Keywords: singing; learning; vocal technique; song

How to Cite: Wadiyo, Utomo, U. \& Haryono, S. (2019). Western Song Singing Model to Improve Junior High School Students' Singing Ability in Indonesia. Harmonia: Journal of Arts Research And Education, 19(1), 48-54.

\section{INTRODUCTION}

Singing is an activity that is usually done by anyone. Expressing a song using a human voice or vocal, usually said as a singing activity. Even though singing is something natural, in Public School including Junior High School level, singing is also becoming one of the teaching materials. In Indonesia, Junior High School belongs to the primary education level which serves students in $7^{\text {th }}, 8^{\text {th }}$, and $9^{\text {th }}$ grade after stu- dents finishing their study in elementary school for their 1 st- $6^{\text {th }}$ grade. The singing lessons for the Junior High School level are included in the teaching materials of cultural arts sub music material. In this sub art of music art, singing activities are often carried out even though there are other aspects of music that are equally important to teach, such as the technique of playing general and local musical instruments and general knowledge about music. Related to this, Chin \& Harrington (2007) stated

\footnotetext{
${ }^{\square}$ Corresponding author: B2 Building, Sekaran, Gunung Pati, Semarang 50229, Indonesia

E-mail: wadiyo@mail.unnes.ac.id
} 
that research suggests that even children with a special gift such as musical ability as part of art or academic, still need to be supported in order to develop their talents and achieve their maximum potential.

Some people have done the results of the research related to learning music and singing, for example, research on how to improve the activities and learning outcomes of Nusantara music appreciation through the use of model songs in VIII grade students of SMP 1 Pangkah Tegal Regency (Herminingrum \& Sumaryanto, 2013). This type of research applies the classroom action research model using two cycles. The first and second cycles use different model songs. The data collection technique is done by observation, documentation, tests, and questionnaires. Based on the problem and the method of research conducted in the research, it can be seen that learning using Nusantara songs can improve the learning activities of singing Nusantara songs and improve the students' appreciation of Nusantara songs. It is also found that model songs are important media to be used as learning media in their relationship to improve music or song learning activities and can be used to improve students' ability to appreciate songs taught by teachers.

The next research study is related to efforts in increasing the interest and learning outcomes of reading musical notes by applying the method of writing beam notation using the Sibelius program in class VII of students in SMPN 4 Ungaran, Semarang Regency (Herdinasari \& Sumaryanto, 2013). The type of research applied is classroom action research by applying the two-cycle steps. The steps are taken to find data until the results obtained using observation, interview, documentation, questionnaires, questionnaires, and performance as an action from the pre-cycle to the final cycle. The results of the study show that the application of learning media using the Sibelius program can increase interest in reading musical notes and increase the results of learning beam notation. The Sibelius program implemented by the te- acher can be used as a method to increase interest in being able to read and write musical notes as well as efforts to improve the ability to read the musical notes.

The description of the results of the research presented here is not similar to the problem and or research objectives to be achieved in this study. The main problem raised in the study is about "how singing activities are taught in the middle class on learning Cultural Arts sub material music." Thus, it is not the same between the problems raised in this study with what has been studied by others. Even though it is not the same, there are still relationships because they are both related to music learning and singing. For that reason, at least the results of the existing research can be used as a guide to see how singing activities are carried out in a teaching and learning process in the Junior High School class in the learning of Cultural Arts submusic material that exists now.

The concepts and or theories used to discuss the problems in this study will certainly relate to creative learning using vocal techniques or singing techniques. What is seen as learning is a business carried out by humans with the intention of facilitating others? Specifically, it can be understood as an effort made by educators with the intention or purpose of helping students so that students get the ease of learning to achieve the desired goals optimally (Gagne et al., 1992). Learning principles can also be seen as being related to learning material or the material being taught. However, it is clear that learning is not just about teaching the material, but it will also always be related to approaches, methods, media use, and evaluations that are associated with learning objectives (Joyce, 1987).

Learning to sing will never be separated from vocal techniques or singing techniques to get maximum results. In singing, at least it must use good and right singing techniques to sound beautiful and not damage the tools attached to the body that are used to produce singing sound. In singing at least there are three breathing 
techniques. Those are sound formation techniques, diction and articulation, and resonance. All of these techniques must be mastered by everyone who will sing to get a sweet and pleasant sound. As previously stated by Brixen, Sadolin, \& Kjelin (2002) and Destiannisa (2012), using the correct technique while singing at the same time will avoid the damage of tools associated with body cells used to produce the singing product.

\section{METHODS}

This research uses interdisciplinary approaches that involve music disciplines and music learning. The research method applied is interpretive qualitative. Based on Myers \& Klein (2001) and Banfield \& Cayago-Gicain (2006) interpretation research methods aim to produce an understanding of the context of information systems, and the process by which information systems influence and are influenced by context. The interpretative qualitative method builds a philosophical and conceptual foundation, so that all the data from the research results are attempted to be interpreted in an emic and ethical manner. The research design applied is a case study by only seeing singing learning in intra-curricular learning at a particular Junior High School education level which in this context is Semarang City Middle School (see Denzin \& Lincoln, 1994). Here is the focus of research, data collection techniques, data validity techniques, and data analysis techniques.

\section{Research Focus}

The focus of this research relates to singing in the learning of sub-material cultural arts at the Junior High School level. Thus, researchers will focus on teaching materials related to vocal techniques and songs used in learning. Singing techniques mainly in breathing techniques, sound formation, diction and articulation, and resonance are the main concerns by also paying attention to whether the teacher conveys the learning objectives of the student, the use of media, the appropriate method, and evaluation or assessment.

\section{Data Collection Techniques}

The first data collection technique is observation. Observations were taken when the teacher taught vocal and singing techniques, precisely how vocal techniques were applied in singing activities. When these singing techniques are given in the learning process, the researchers, as an observer really pay attention. The researcher pays attention to learning from starting the lesson until giving core material and closing. The detail that is found in observation is interviewed to the teacher and some students. What taught by the teacher is also seen in the documentation relating to the planned implementation of learning (Silverman, 2000).

\section{The technique of data validity and data analysis}

What the researchers did in the data validity technique here was primarily to match the data obtained from observation, interviews, and documentation studies (Smith, 2003). Data analysis uses an interactive analysis carried out starting from data collection, data reduction, data presentation, and verification or conclusions (Dey, 1993). In short, departing from the field, data obtained from observations, interviews, and study documentation by researchers is reduced, presented in descriptive analytical form, and verified as commonly used in a qualitative study. To see the reliability and validity of the data, researchers were assisted by research members in observing several schools. Likewise in interviews and looking for documentation data, researchers were also assisted by team members and several other aid workers. In the end, all the data obtained were analyzed using an interactive model that was always interpreted by researchers so that emic ethics always walk together (Amady, 2015). 


\section{RESULTS AND DISCUSSIONS}

In this part, the results and discussion of the study are reported. It is an effort to make the results of the research and discussion clearer. In this study, the results of the research and discussion were put together united or not separated. The following are the results of the study with this discussion delivered from the opening of learning, the delivery of the content of teaching material, and concluding to find out how actually this singing activity is delivered as a learning process to be seen in terms of the process and products.

\section{Opening of Singing Lesson}

In learning to sing in front of the class, the teacher opens the lesson by explaining the singing technique to be able to sing well and correctly to the students. As an effort to be able to sing well and correctly, there are some steps to be followed. The first way is to master the breathing technique. Second is forming sound capability. Third is mastery of diction and articulation. Fourth is the capability of utilizing resonance. For the opening of this learning the teacher has delivered the learning objectives but the media and teaching methods are still very conventional. It is still just oral that the teacher has not really used the media and applied the method according to the teaching material given.

According to Jacobs, Renandya, \& Power (2016) actually there was already a general description in accordance with the main elements of learning that must be delivered in the opening lesson which were not only related to apperception but also the delivery of learning objectives. It is should be given by describing teaching material to be delivered. In addition, the media and the delivery method should have been implemented and there was also a little evaluation related to what was conveyed in the opening. Thus, even though it is still in its opening stage, everything that will be delivered in the core material of the lesson has been clearly described.

\section{Submission of Learning Content}

In this submission of learning content, the teacher explains the learning texts delivered to the students, in which the knowledge and practice are incorporated. This can be said in accordance with what is the goal of art education that in art education all things theory and or knowledge must be dissolved with practice so that students can learn music with musical experience (Welch, et al. (2004)) and or through learning art can be gained experience aesthetics (Sutherland, 2013).

\section{Mastery of breathing techniques in sing- ing}

It was conveyed in learning to sing that there are 3 breathing techniques namely shoulder breathing, chest breathing, and diaphragmatic breathing. In shoulder breathing, it is done by taking a breath with part of the lungs being developed so that the shoulder is pushed up. Breath in this way is very shallow, it doesn't last long and the posture becomes less beautiful. Chest breathing, carried out with full breath inserted in the lungs so that the chest cavity penetrates forward. The weakness of this technique is that the lungs quickly become tired in holding the air. Here the sound produced is not stable because the released air is not produced well.

In diaphragmatic breathing, the lungs can be fully filled without being pinched because the room is expanded by tightening the bulkhead of the body cavity or the diaphragm moving downward. Here the lungs expand slightly. Expulsion of breath occurs with the diaphragm pressing against the lungs from below and assisted by the abdominal muscles and muscles of the body. Thus, the expenditure of breath is governed by our own will and produces a convincing sound. From all those three types of breathing technique to sing, diaphragm is the best breathing. However, it is believed that not everyone can do this diaphragmatic breathing (Sundberg, 1992). 


\section{Sound Formation}

Before we sing, we have to pump the air into the lungs sent by the muscles of the abdomen, the chest muscles and the muscles of the body and the diaphragm. Then the air is blown out in a way that vibrates the vocal cords. Then the vibrations become clear and beautiful sounds in the oral cavity. The ability to pronounce both vowels and letters is because humans have pronunciation tools or articulations. The articulation tools are lips, teeth, tongue, hard palate and soft palate, oral cavity, nasal cavity, and pharynx (Sundberg, 1992).

\section{Articulation}

Articulation is understood as speech clarity. In singing, articulation this connects to form a clear but beautiful sound. The way to produce good diction and articulation is to open your mouth wide. The width in opening the mouth to produce the expected sound is by pulling the jaw down. Use reasonable letters to train, namely letters a, i, $u, e, o$ in a repetitive manner. After that the vowels can be connected with dead letters and finally can be with any word. All is done naturally but the principle is to form a clear but beautiful voice with the shape of the mouth that really matches the letters or words spoken (Wolfe, Garnier, \& Smith, 2009).

\section{Resonance}

In music, what is called as resonance is actually a word or term that has something to do with many spaces or cavities in the human body. In singing, the cavities must be utilized. The main resonance cavity is on the head, where there are many air chambers that are very influential in tone formation. The vocal cords radiate into the air in the chambers, which reflect sound to be strong. The quality of the singer's tone depends on utilizing this resonance. The most important thing in relation to this resonance is that in singing it must utilize the resonance in the head. The main purpose of singing is to create a beautiful sound. Not just loud (Wolfe et al., 2009).

\section{Closing of Learning to Sing}

In the activity of closing this learning, what is more, emphasized by the teacher is making sure that the students have done singing practice activities, whatever results are achieved. This is in accordance with Nilson, McMurray, \& Fetherston (2013) who argued that the purpose of learning the art of music in schools is to develop attitudes and abilities so that students are able to be creative and sensitive in the arts, or provide the ability to work and appreciate art. Regarding the knowledge of what conditions must be mastered by someone to be able to sing well and correctly, not only delivered in the opening session of learning but actually practiced in the content of the lesson and still re-emphasized in closing the lesson. Therefore, the subject matter of teaching material can be delivered following the learning objectives set. The activity closes the lesson and reminds students that teachers always do that students try to always learn about the material provided.

\section{CONCLUSION}

In learning to sing, what is prioritized by the teacher is the knowledge of the basic techniques of singing and practicing in singing activities. The teachers make this singing technique a guide to singing any song. If the material sung is a diatonic song, this technique is a singing technique that fits right because this singing technique does adopt from what is in diatonic music. The problem is to sing pentatonic songs and or traditional non-Western songs. This is the habit of the Indonesian music teachers that whatever singing material is, all the tones are changed to diatonic notes or notations. As the example is the Javanese songs that are having pelog and slendro are finally made diatonic notations so that the technique of singing local songs or native regions that are always present in each region does not appear. 


\section{REFERENCES}

Amady, M. R. El. (2015). Etik dan Emik pada Karya Etnografi. Jurnal Antropologi: Isu-Isu Sosial Budaya, 16(2), 167-189. Retrieved from http://jurnalantropologi.fisip.unand.ac.id/index.php/jantro/article/view/24/29

Banfield, G., \& Cayago-Gicain, M. S. (2006). Qualitative approaches to educational evaluation: A regional conference-workshop. International Education Journal, 7(4), 510-513.

Brixen, E. B., Sadolin, C., \& Kjelin, H. (2002). Convention Paper. Audio Engineering Society, 14(1), 1-13.

Chin, C., \& Harrington, D. (2007). Supporting the Development of Musical Talent. Gifted Child Today, 30(1), 40-65.

Denzin, N. K., \& Lincoln, Y. S. (1994). Handbook of qualitative research. Handbook of qualitative research. California: SAGE. https://doi.org/http:// www.uncg.edu/hdf/facultystaff/ Tudge/Guba \% 20\&\%20Lincoln \% 20 1994.pdf

Destiannisa, A. (2012). Implementasi Metode Pendekatan Kognitif Dalam Pembelajaran Paduan Suara. Harmonia: Jurnal Pengetahuan Dan Pemikiran Seni, 12(2), 160-166.

Dey, I. (1993). Qualitative Data Analysis. New York: Routledge.

Gagne, R. M., Briggs, L. J., Buchholz, T., Weaver, J., Wiggins, A. D., \& Draper, G. (1992). Principles of Instructional Design Fourth Edition (Fourth Edi). Orlando: Harcourt Brace Jovanovich College Publishers. https://doi. org/10.1002/pfi.4140440211

Herdinasari, T. R., \& Sumaryanto, F. T. (2013). Upaya Meningkatkan Minat dan Hasil Belajar Membaca Notasi Musik Balok melalui Media Pembelajaran Sibelius pada Siswa kelas VII G SMP Negeri 4 Ungaran. Jurnal Seni Musik, 2(2), 2-6.

Herminingrum, E., \& Sumaryanto, F. T. (2012). Jurnal seni musik. Jurnal Seni Musik, 2(1), 59-67. Retrieved from http://journal. unnes.ac.id/sju/index.php/ jsm\%0AMENINGKATKAN

Jacobs, G. M., Renandya, W. A., \& Power, M. (2016). Simple, Powerful Strategies for Student-Centered Learning. Springer. https://doi.org/10.1007/978-3319-25712-9

Joyce, B. R. (2016). Learning How to Learn Time as we have attempted to classify alternative. Theory Into Practice, 26, 416-428. Retrieved from https:// www.jstor.org/stable/1476262

Myers, M., \& Klein, H. (2001). A classification scheme for interpretive research in information systems. Qualitative Research in IS Issues and Trends, (April 2001), 218-239. https:// doi.org/http://doi.org/ http://dx.doi.org.ezproxy.uct. ac.za/10.4135/9781473914209

Nilson, C., Fetherston, C., McMurray, A., \& Fetherston, T. (2013). Creative Arts: An Essential Element in the Teacher's Toolkit When Developing Critical Thinking in Children. Australian Journal of Teacher Education, 38(7). $\quad$ https://doi.org/10.14221/ ajte.2013v38n7.4

Silverman, D. (2000). Doing qualitative research: A practical handbook. California: Thousand Oaks, SAGE.

Smith, Y. (2003). Understanding reliability and validity in qualitative research. The Qualitative Report, 8(4), 597-607. Retrieved from http://www.newsmedical.net/health/ThalassemiaPrevalence.aspx

Sundberg, J. (1992). Quarterly Progress and Status Report Breathing behavior during singing. STL-QPSR, 33(1), 049-064. Retrieved from http:// www.speech.kth.se/qpsr /

Sutherland,I. (2013). Arts-based methods in leadership development: Affording aesthetic workspaces, reflexivity and memories with momentum. Management Learning, 44(1), 25-43. https:/ / doi.org/10.1177/1350507612465063

Welch, G., Hallam, S., Lamont, A., Swanwick, K., \& Hennessy, S. (2004). Mapping music education re- 
search in the UK. Psychology of Music. Retrieved from https://doi. org/10.1177\%2F0305735604043257

Wolfe, J., Garnier, M., \& Smith, J. (2009). Vocal tract resonances in speech, singing and playing musical in- struments. Human Frontier Science Program Journal, 3, 6-23. Retrieved from papers2://publication/ uuid/436A9EA1-DB8E-4D27-90B72DBB1125F93E 